\title{
PREgLED NACIONALNIH MODELA SPORTSKE DIPLOMACIJE U SVIJETU \\ I PERSPEKTIVA RAZVOJA HRVATSKOG MODELA SPORTSKE DIPLOMACIJE
}

\author{
Luka Leško \\ Zagrebačka škola ekonomije i managementa
}

\begin{abstract}
SAŽETAK
Ulogu sporta kao sredstva diplomacije zagovaraju predstavnici konstruktivističke teorije međunarodnih odnosa. Cilj rada je dati pregled nacionalnih modela sportske diplomacije (Australije, Francuske, SAD, Norveške, Rusije, Kine, Japana i Brazila), te ukazati na perspektivu razvoja hrvatskog modela sportske diplomacije. Pozitivni učinci sporta na državne ciljeve ostvaruju se putem nacionalnih modela sportske diplomacije koji obuhvaćaju: korištenje sportske uspješnosti u jačanju meke moći države, uključenje sportaša u političke i diplomatske procese, korištenje sporta kao diplomatskog instrumenta putem međunarodnih razvojnih programa, organizaciju sportskih događaja itd. Identificirana su područja na koja hrvatski sport može pozitivno utjecati, poput međunarodnih odnosa, poboljšanja imidža države u svijetu, jačanja nacionalne kohezije, zatim turističke, demografske, ekonomske i javnozdravstvene dobrobiti, socijalne inkluzije, jačanja kulture volonterizma itd. Sustavno prepoznata važnost sporta od strane države od krucijalnog je značaja. Preporučuje se međuresorna izrada nacionalne strategije sportske diplomacije ili separatnih programa sa sličnim ciljevima.
\end{abstract}

KLJUČNE RIJEČI: meka moć, strategija, međunarodni odnosi, vanjski poslovi, Olimpijske igre

\section{Kontakt autora:}

Luka Leško, Zagrebačka škola ekonomije i managementa, Jordanovac 110, 10 ooo Zagreb. E-pošta: llesko@zsem.hr 
POLITIČKE PERSPEKTIVE

ČLANCI I STUDIJE

\section{UVOD}

S različitim pogledima na pitanje moći, u teoriji međunarodnih odnosa razlikuju se tri dominantna teorijska pristupa koji oblikuju politički diskurs i političku analizu: realizam, liberalizam i idealizam (Walt 1998). Moć je sastavni element društveno-političkih odnosa. Klasično realističko određenje moći, izvedeno iz analize političke sfere društvenog djelovanja, ono Maxa Webera, tvrdi da je moć sposobnost da se vlastitom voljom drugima nameće željeno ponašanje. Moć je, dakle, sposobnost pojedinca i skupina da provedu vlastite ciljeve, čak i kada im se drugi protive (Haralambos and Holborn 2002; Kalanj 2010; Weber 2013). Realizam se referira na raspodjelu moći među državama, liberalizam ističe sve veći broj demokracija, a idealizam promjenjive norme suverenosti i ljudskih prava (Mingst and Snyder 2014). Za realiste je moć ključan čimbenik koji određuje ponašanje države. Iako ne smatraju moć irelevantnom, konstruktivisti su usmjereni na stvaranje i evoluciju ideja i identiteta, te njihov utjecaj na način kako države shvaćaju određeni kontekst i ponašaju se u tim situacijama (Walt 1998). Suprotno realističkim shvaćanjima, konstruktivisti (oblik idealizma) smatraju kako čimbenici društvenog života nisu konstantni. Teorije konstruktivizma polaze od različitih faktora utjecaja (socijalizacija, interakcija, učenje između država) na formiranje identiteta, koji determinira ponašanje država u dvije dimenzije: kako država vidi sebe, te kako je vide druge države (Frazier and Stewart-Ingersoll 2010). Društvena realnost nije zadana i nepromjenjiva, već se nalazi u subjektivnoj percepciji aktera međunarodnih odnosa. Za razliku od liberalizma i realizma kao racionalističkih teorija međunarodnih odnosa, konstruktivizam upućuje na ideje i vjerovanja svakog pojedinca, te na njihovu interakciju (Jackson and Sørensen 2007).

Jedna od suvremenijih istraživačkih tema međunarodnih odnosa jest sport. Prema Cashmore (2005), sport je kao institucija ekonomski prevelika, politički previše važna, previše utjecajna u oblikovanju ljudskih života, da je ne bismo smatrali ozbiljnom temom istraživanja. Sport je jedna od temeljnih društvenih institucija, neodvojiv od institucija obitelji, gospodarstva, politike i sl. (Perasović i Bartoluci 2007), a njegova snaga leži i u specifično velikom medijskom prostoru koji ostvaruje. Winstanley (2009) upućuje kako sport okupira tzv. silent space u međunarodnim odnosima, uz sugestiju kako bi proučavanje međunarodnih odnosa trebalo prevladati stroge granice koje razdvajaju političko i nepolitičko, što potiče upravo konstruktivističku interpretaciju stvarnosti. Taylor (1986) ukazuje da bi teoretičari međunarodnih odnosa trebali obratiti pažnju na sport jer je riječ o važnom društvenom čimbeniku, koji može utjecati na artikulaciju u međunarodnim odnosima. Houlihan (1994) je detektirao pet dodirnih područja sporta i međunarodne politike: diplomacija, ideologija, izgradnja 
LUKA LEŠKO

PREGLED NACIONALNIH MODELA SPORTSKE DIPLOMACIJE U SVIJETU I PERSPEKTIVA RAZVOJA HRVATSKOG MODELA SPORTSKE DIPLOMACIJE

nacije, pristupačnost i novac. Sportska diplomacija jedno je od područja na kojemu se zbiva transformacija diplomacije. Neopipljiva moć sporta primjer je kombinacije javne i kulturne diplomacije (Luša 2016). Sportska diplomacija podrazumijeva niz formalnih i neformalnih akcija države, diplomatskih misija, sportskih dužnosnika, sportaša i drugih aktera u svrhu implementacije vanjske politike putem sporta (Muzhikbeav 2014). Sport je korišten kao geopolitičko oružje (pri bojkotu velikih sportskih natjecanja), kao sredstvo jačanja nacionalizma, izgradnje nacionalnih država i identiteta, kao medij za prenošenje političkih poruka, promicanje dijaloga i integracije u multikulturalnim društvima, te kao sredstvo radikalizacije odnosa među državama (Mabillard and Jádi 2011). Ulogu sporta kao sredstva diplomacije zagovaraju upravo predstavnici konstruktivističke teorije međunarodnih odnosa (Luša 2016). Suprotno realističkoj koja počiva na materijalnim aspektima moći, teorija konstruktivizma ističe važnost meke moći (soft power), kroz čiju se prizmu može tumačiti uloga sporta kao sredstva diplomacije. Najveći doprinos konceptu meke moći pružio je Joseph Nye, definirajući taj pojam sposobnošću nacije da postigne željeni ishod bez primjene sile ili plaćanja, već kroz privlačenje putem vlastite kulture, političkih vrijednosti, unutarnje i vanjske politike (Nye 2004). Uporaba sporta u uključivanju države u međunarodnu zajednicu, slanju diplomatskih poruka ili ispitivanju temelja za buduće pregovore upućuje kako je sport postao neopipljivom sastavnicom vanjske politike.

Sport uživa poseban status u društvu još od antičkih vremena. Antičke Olimpijske igre održavane su na svetom mjestu tijekom svetog praznika, a olimpijsko primirje državama sudionicama zabranjivalo je ratovanje za trajanja natjecanja. Miting Francoisa I i Henrika VIII godine 1520. u sjevernoj Francuskoj, gdje su se njihovi vojnici natjecali u streličarstvu, organiziran je u svrhu jačanja međudržavnih odnosa nastavno na anglofrancuski sporazum iz 1514. godine (Mattingly 1938). U novijoj povijesti upečatljiv je prekid paljbe u jeku Prvoga svjetskog rata na Božić 1914, zbog odigravanja nogometne utakmice između neprijateljskih britanskih i njemačkih vojnika. Najveće sportske priredbe poslužile su promociji ideologija režima, slanju diplomatskih poruka (npr. bojkot Olimpijskih igara) i sl. Sport, politika i diplomacija odavno su kompatibilni, a kada sport generira dobrobiti, postaje i politički zanimljiv (Jackson and Haigh 2008).

U posthladnoratovskom razdoblju, novonastale države uglavnom su aplicirale za članstvo u Međunarodnom olimpijskom odboru i Svjetskoj nogometnoj federaciji, prije nego u Ujedinjenim narodima (Levemore and Buss 2004). Takvome pristupu svjedočimo i današnjih dana. Kosovo, između ostaloga, put međunarodnoj integraciji gradi i kroz sport, a Međunarodni olimpijski odbor u članstvo ih je primio još 2014. godine. Za istaknuti je i zajednički nastup dviju Koreja u hokeju na ledu zabilježen na 
zimskim OI 2018, te na muškom rukometnom Svjetskom prvenstvu 2019. g. Zbog globalne rasprostranjenosti sporta i njegove uloge $u$ integraciji u multikulturalnim društvima, Ujedinjeni narodi ga prepoznaju instrumentom za prosperitet u različitim sferama života (zdravlju, obrazovanju, održivu razvoju, očuvanju mira i komunikaciji), u svrhu čega je oformljen i Office on Sport for Development and Peace (UNOSDP). Gotovo sve kulture iskazuju interes prema sportu, što ga čini pogodnim za razmjenu političkih poruka. Inuiti su, primjerice, jednako zainteresirani za Svjetsko nogometno prvenstvo kao i stanovnici Argentine, Konga ili Europe (Redeker 20o8).

Dok se odnos diplomacije i sporta može činiti očiglednim, ta je tema dugo bila nedostatno proučavana (Murray and Pigman 2014; Murray 2018). Za Pammenta (2016), sportska diplomacija je područje istraživanja koje ima važnu ulogu u konceptualizaciji veza između različitih diplomatskih koncepata, te njihovog međusobnog i komplementarnog utjecaja na međunarodno okruženje. Keech (2001) je u širem smislu objašnjava nizom međunarodnih kontakata i kompetitivnosti, koji imaju implikacije na sveukupne odnose između država. Sportska se diplomacija obično smatra oblikom javne diplomacije. Ociepka (2013) ističe da sport ima značajnu ulogu u javnoj diplomaciji u funkciji jačanja međunarodnog ugleda zemlje. Iako Murray (2011) također smatra da je sportska diplomacija sastavni dio javne diplomacije, Mabillard i Jádi (2011) smatraju da je sport bliži kulturnoj diplomaciji. Kako god uzevši, brojni su znanstvenici i državnici prepoznali meku moć sporta u ostvarenju državnih ciljeva, što će u nastavku biti elaborirano putem konkretnih modela sportske diplomacije diljem svijeta. Murray i Pigman (2014) dali su slikovit opis: „Ako tradicionalnu diplomaciju nazivamo sredstvom vanjske politike, sportska diplomacija predstavlja sredstvo toga sredstva”. Na razini Europske unije, koncept sportske diplomacije formalno je prepoznat 2015, kada je oformljena ekspertna skupina za sportsku diplomaciju (Europska unija, 2019). Murray i Pigman (2014) ističu dvije glavne kategorije primjene sportske diplomacije: državnu uporabu sportskih postignuća kao instrumenata diplomacije (sportska kompetitivnost), te uporabu sporta u svrhu komunikacije, pregovora i slanja diplomatskih poruka. U tom smislu, Vlade nerijetko angažiraju sportaše kako bi osnažile diplomatske poruke, te koriste sportske događaje u svrhu smirivanja napetosti diplomatskih odnosa ili testiranja temelja za primjenu budućih politika. Jedan od upečatljivijih primjera je imenovanje osvajača Zlatne lopte, nogometaša Georgea Weaha, predsjednikom Liberije.

Vraćajući se u povijest, još 1961. godine Savezno ministarstvo vanjskih poslova Njemačke koristilo je sport kao instrument mirovne politike prema zemljama u razvoju, kako bi ublažilo predrasude o Njemačkoj (Auswartiges 2010). Vjerojatno najpoznatiji primjer sportske diplomacije jest stolno- 
teniska razmjena između američke i kineske reprezentacije u periodu zaoštrenih odnosa sedamdesetih godina. Taj je događaj omogućio obnovu kinesko-američkih odnosa, te bio uvod u povijesni posjet američkog predsjednika Nixona Kini 1972. godine, od kada i datira pojam ping-pong diplomacije. Nakon što je Kašmirska kriza 2002. ostavila Indiju i Pakistan na rubu rata, te su države tijekom 2004. održale niz kriket mečeva radi smanjenja napetosti i ispitivanja mogućnosti normalizacije odnosa, otvaranja granica i nastavka pregovora. Nakon terorističkih napada u Mumbaiju 20o8, odnosi su iznova zamrznuti, a kriket je ponovno iskorišten kao diplomatski alat, koji je odigrao važnu ulogu u normalizaciji odnosa (Rupert 2011). Slične ciljeve imale su inicijative tzv. bejzbol diplomacije na relaciji SAD-Kuba, te tzv. nogometne diplomacije na relaciji Turska-Armenija (Murray and Pigman 2014). Sport je poslužio kao važan instrument i tijekom pobjede Južnoafričke Republike na Svjetskom ragbi prvenstvu 1995. godine, što se smatra godinom ujedinjenja nacije nakon pretrpljenih poteškoća uzrokovanih apartheidom.

Međutim, bilo je i slučajeva kada su sportski događaji potaknuli eskalaciju sukoba između zemalja. Godine 1969. došlo je do kraćeg rata između Salvadora i Hondurasa nakon završetka kvalifikacija za Svjetsko nogometno prvenstvo 1970. godine. Honduras je pobijedio u prvom susretu u Tegucigalpi, a Salvador u drugom i trećem meču u San Salvadoru, odnosno Mexico Cityju, te ostvario ukupnu pobjedu. Pobjeda salvadorskog tima u Meksiku rezultirala je trenutnim prekidom svih diplomatskih odnosa između dviju zemalja. Rat je započeo 14. srpnja, kada je salvadorska vojska napala Honduras. Organizacija Američkih Država (OAS) dogovorila je primirje, koje je stupilo na snagu 20. srpnja. Unatoč prevladavanju sukoba, ostali su napeti odnosi između tih dviju zemalja (Murray and Pigman 2014). S obzirom na nedostatak studija na temu sportske diplomacije u Republici Hrvatskoj, cilj ovoga rada je dati pregled nacionalnih modela sportske diplomacije u svijetu, te ukazati na perspektivu razvoja hrvatskog modela sportske diplomacije.

\section{Pregled NACIONALNiH MODELA SPORTSKe DIPLOMACIJE U SVIJETU}

Kroz različite pristupe sportskoj diplomaciji u zemljama diljem svijeta, prikazat će se njihovi ciljevi i sredstva, a u određenim primjerima i organizacijski nositelji provedbenih strategija i programa sportske diplomacije. Australija posjeduje najopsežnije studije i programe sportske diplomacije (Grassroots Sport Diplomacy 2018). Koncept sportske diplomacije sustavno je prepoznat na najvišoj državnoj instanci, a temeljen na međunarodnoj reputaciji Australije kao sportske zemlje (Department of Foreign Affairs and Trade of Australian Government 2015). Prepoznati su učinci 


\section{2 \\ POLITIČKE PERSPEKTIVE}

ČLANCI I STUDIJE

sportske diplomacije na važne demografske pokazatelje, migracijske tokove (australska dijaspora i indopacifička zajednica), ekonomske, investicijske i ostale domene od državnog interesa, u svrhu čega je kreirana posebna strategija. Prema Department of Foreign Affairs and Trade of Australian Government (2015), izrada i provedba Nacionalne strategije sportske diplomacije prilagođena je standardnim strateškim državnim ciljevima, a u zajedničkoj je nadležnosti Ministarstva vanjskih poslova i trgovine (DFAT), Državnog ureda za sport, Državne komisije za trgovinu i ulaganja (Austrade), Vladine agencije za privlačenje inozemnih posjetitelja u Australiju (Tourism Australia), te Nacionalne sportske komisije. U operativnom smislu, sportske organizacije imaju važnu ulogu u osmišljavanju i provedbi aktivnosti (Olimpijski odbor, nacionalne i lokalne sportske organizacije). U svrhu maksimalne aktualizacije naglašen je komplementarni pristup iskorištavanju dobrobiti sporta u različitim sferama društvenog života, putem međuresorne suradnje te suradnje, s vanjskim partnerima (Australian Sports Diplomacy Strategy 2015-18). Aktivnosti se provode putem ostvarenih poticaja, državnih ulaganja, outsourcing suradnje s partnerima iz sportske industrije i sl. Izrada, provedba i evaluacija temeljena je na objektivnim pokazateljima (turistički, medijski i ekonomski pokazatelji, ostvarena sponzorstva, pro bono podrške, broj manifestacija itd.), a formirana su četiri glavna cilja (prema Australian Sports Diplomacy Strategy 2015-18):

1) Povezivanje ljudi i institucija;

2) Sport za razvoj (prevencija nezaraznih bolesti, podrška osobama s invaliditetom, inkluzija ranjivih skupina, usvajanje zdravih navika putem sporta, razvojni programi, volonterizam, programi potpore okolnim zemljama itd.);

3) Imidž države (nadmetanje za organizaciju velikih sportskih priredbi, izgradnja sportske infrastrukture, inovativnost u sportskoj industriji, sportskoj medicini i prehrani s naglaskom na izvozne mogućnosti);

4 Potpora inovacijama i regionalnoj suradnji (australska sportska industrija i obrazovne institucije imaju dobro uspostavljene veze s indopacifičkim kolegama u nizu aktivnosti poput zajedničkih domaćinstava sportskih natjecanja, sportsko-investicijskih partnerstava u obrazovanju, osposobljavanju i razvoju putem brojnih projekata i sl.).

Prema France Diplomatie (2019), Francuska je zemlja s gotovo 50.000 sportskih udruga, u kojima radi oko 165.000 zaposlenika. Radna snaga u francuskom sportskom sektoru u posljednjih se 20 godina učetverostručila. Također, ta zemlja ima oko 16.0oo.ooo članova sportskih udruga, te razvijenu kulturu volonterizma (oko 3.500.ooo volontera). S prometom 
od oko 34.000.000.ooo eura, sportski sektor čini 1.9\% francuskog BDP-a (France Diplomatie 2019). Na državnoj razini, prepoznata je uloga sporta u gospodarskom razvoju i jačanju međunarodnog utjecaja. U formalnom smislu, francuska sportska diplomacija uspostavljena je 2014, a danas je sport sastavni dio javne diplomacije (Grassroots Sport Diplomacy 2018). Francusko Ministarstvo vanjskih poslova i Ministarstvo sporta zajednički su kreirali službeni model sportske diplomacije. Uspostavljena je međuresorna delegacija za velike sportske događaje (DIGES), kao i Ured za profesionalni sport i sportsku ekonomiju. Kreirana su ambasadorska mjesta (sportski veleposlanik) pri Odboru za međunarodni sport (CFSI), u suradnji s Nacionalnim olimpijskim odborom. Prema Grassroots Sport Diplomacy (2018), temeljni ciljevi francuske sportske diplomacije obuhvaćaju širenje međunarodnog utjecaja Francuske kroz sport, korištenje ekonomske dobrobiti sporta, te isticanje njegove važnosti u različitim domenama društvenog života. S obzirom na promocijske učinke velikih međunarodnih sportskih manifestacija (Bamossy and Stephens 2003; Chalip, Green and Hill 2003; Oldenboom 2006), smatraju da sportske priredbe održane u Francuskoj doprinose pozitivnoj slici o zemlji u svijetu (u smislu infrastrukture, poslovnih partnerstava, turizma, gostoljubivosti i demonstracije stručnosti u oblasti organizacije sportskih događaja). Iako generiraju i dugoročne turističke učinke, veliki sportski događaji zahtijevaju značajna ulaganja u sportsku, ali i ostalu propratnu infrastrukturu, pri čemu je važno uklapanje takvih ulaganja u dugoročne strateške planove gradova domaćina u svrhu ekonomske održivosti (Solberg and Preuss 2007). Francuska posjeduje kapacitete za održavanje najvećih natjecanja, a Olimpijske igre kao najveću globalnu sportsku smotru ugostit će 2024. godine u Parizu. Francuzi strateški teže i očuvanju francuskog kao službenog jezika u najutjecajnijim međunarodnim sportskim organizacijama, kao i prisutnosti francuskih povjerenika u tijelima takvih organizacija. Francuski odbor za međunarodni sport, Francuski olimpijski odbor, sportski veleposlanici, te veleposlanstva u inozemstvu s imenovanim sportskim predstavnicima, zajednički teže povećanju broja velikih sportskih priredbi u Francuskoj, što omogućuje i povećanje zapošljavanja, a s drugim resorima sudjeluju u kreiranju aktivnih mjera poticanja inozemnih posjetitelja na pohođenje sportskih događaja u Francuskoj. Osim toga, sustavno rade na identifikaciji i predikciji benefita nastupa francuskih sportaša na natjecanjima u inozemstvu, te uključivanju istaknutih sportaša u predsjedničke i ministarske posjete drugih država. U najvažnijim međunarodnim tijelima poput UN-a, zagovaraju važnost i etičnost sporta, a francuskim sportski orijentiranim tvrtkama i organizacijama pružaju potporu u tržišnom nadmetanju, odnosno kandidaturi za organizaciju sportskih priredbi. 
Da je sport domena od državnog interesa prepoznale su i Sjedinjene Američke Države. Organiziran od strane State Departmenta, "Global Sports Mentoring Program” osigurava edukaciju potencijalnih američkih sportskih diplomata diljem svijeta (Bureau of Educational and Cultural Affairs 2019). Prema Waltersu (2007), Ministarstvo vanjskih poslova SAD redovito zapošljava sportske diplomate, poput klizačice Michelle Kwan i bejzbolske zvijezde Cala Ripkena. Ministarstvo vanjskih poslova i ESPN glavni su partneri u području sportske diplomacije, iako su uključene i brojne druge institucije, poput Centra za sport, mir i društvo Sveučilišta Tennessee (Bureau of Educational and Cultural Affairs 2019). Nakon terorističkih napada 11. rujna 2001, SAD je koristio sport u svrhu inkluzije muslimana diljem Afrike, Bliskog istoka i Južne Azije, putem podrške u učenju engleskog jezika. State Department snažno zagovara korištenje sporta kao diplomatskog instrumenta i kroz "SportsUnited" programe (Bureau of Educational and Cultural Affairs 2019). Primjeri razvojnih programa najbolje se oslikavaju u suradnji s Meksikom, organizacijom zajedničkih sportskih događaja u svrhu poboljšanja odnosa među zemljama u različitim sferama društvenog života. U tom kontekstu, znakovito je i Svjetsko nogometno prvenstvo, koje će 2026. godine biti zajednički organizirano u SAD, Meksiku i Kanadi. Kandidatura je nosila naziv “United 2026”. U kontekstu najvećih sportskih događaja, Los Angeles je pobijedio u izboru za domaćinstvo Olimpijskih igara 2028. godine. U smislu ekonomske dobrobiti sportskih događaja, Sprecher (2018) ukazuje na sljedeće učinke sportskih natjecanja održanih 2018. godine u SAD, a koji uključuju čak i natjecanja mlađih dobnih kategorija: NCAA Final Four (38.ooo noćenja, ukupan ekonomski prihod od 185.0oo.ooo dolara), AAU Junior National Volleyball Championships (112.0oo noćenja, ukupan ekonomski prihod od 91.0oo.ooo dolara), Austin Marathon (1.616 noćenja, ukupan ekonomski prihod od 37.500.0oo dolara), Publix Savannah Women's Half Marathon \& 5K (4.559 noćenja, ukupan ekonomski prihod od 4.100.0oo dolara).

Norveška je zemlja od oko 5.200.ooo stanovnika. Unatoč tomu što sport nije prepoznat jednim od glavnih elemenata brendiranja norveške nacije, ta država pruža pomoć u razvoju sportova manje razvijenih zemalja još od osamdesetih godina, a danas ima usvojenu službenu strategiju javne i sportske diplomacije (Kobierecki 2017). Njihove su glavne težnje usmjerene organizaciji velikih sportskih priredbi, te održavanju sportske uspješnosti, dominantno u zimskim sportovima. Prema Kobiereckom (2017), norveški sportski rezultati plod su strategije (nakon „Projekta 88” iz osamdesetih godina, uslijedio je “The Norwegian model”, a zatim oformljena i Olympiatoppen organizacija). Prema Yichen i sur. (2011), pozitivni učinci organizacije Olimpijskih igara očituju se u marketinškom, medijskom, poslovnom i turističkom smislu, u području transporta, ugostiteljstva, otvaranja radnih 
mjesta itd. Smatrajući kako je organiziranje velikih sportskih događanja vjerojatno najsnažnija metoda međunarodnog brendiranja države jer veliki broj ljudi posjećuje natjecanja, a još ih više prati putem medija, Norveška je dva puta bila domaćin zimskih Olimpijskih igara (1952. u Oslu i 1994. u Lillehammeru). Oslo je ponovno podnio kandidaturu za domaćinstvo ZOI 2022. godine, ali je povučena zbog zabrinutosti o financijskoj održivosti (Abend 2014). Konstantno održavanje manje poznatih, ali tradicionalnih međunarodnih sportskih događaja poput "Norway Cupa”, drugog najvećeg nogometnog turnira za mlade u svijetu, jedna je od važnijih zadaća nacionalne strategije sportske diplomacije u Norveškoj (Kobierecki 2017). Njihov ministar vanjskih poslova izjavio je da "Norway Cup" ima važnu ulogu u podupiranju internacionalizma i suradnje Norveške s Brazilom, Kenijom i Palestinom. U okviru sportske diplomacije, Norveška dodjeljuje stipendije stranim studentima za studiranje na norveškim sveučilištima (Jarvie 2015), kako bi mladim osobama iz inozemstva pružili priliku za upoznavanje s vrijednostima Norveške, koja tako postaje vidljivijom i pristupačnijom (Kobierecki 2017).

Rusija vidi sport kao podlogu jačanju međunarodnog utjecaja i rješavanju sukoba, organizacijom velikih sportskih priredbi, te uključivanjem sportaša u političke i diplomatske procese. Slučaj rusko-gruzijske sportske diplomacije pokazuje da je, čak i kada zemlje nemaju diplomatske odnose, važno ulagati napore u ostvarenju suradnje. Godine 20o8. Rusija i Gruzija su prekinule diplomatske odnose (Velikaya 2016). Bilateralni dijalog je podržan u okviru Ženevskih rasprava o sigurnosti i stabilnosti na Južnom Kavkazu. Činjenica da unatoč političkim nesuglasicama sportaši i dalje neprekidno surađuju poslužila je i pri diplomatskom posjetu troje proslavljenih ruskih sportaša Gruziji (hrvač Aleksandr Karelin, gimnastičarka Svetlana Khorkina i plivač Alexander Popov). Rusi su predložili uspostavu dobrosusjedskih odnosa između dviju zemalja, prisjećajući se na zajedničku povijest (Velikaya 2016), a događaj je polučio određene pozitivne učinke, što je posebno važno znajući podatak da stotine tisuća Gruzijaca radi u Rusiji. Predsjednik Putin jedan je od globalno najistaknutijih zagovaratelja sporta, a zimske OI u Sočiju, te Svjetsko nogometno prvenstvo 2018. organizirani su kako bi, između ostaloga, poslužili poboljšanju slike o Rusiji u svijetu (Manurung 2018). Prema Aubinu (2017), navedene sportske manifestacije važan su alat ruske vanjske politike, mobilizirajući lokalnu elitu (oligarhe, političare, tvrtke i sportaše) no, unatoč tomu, sustavna (programska) sportska diplomacija je u Rusiji još uvijek relativno nova pojava.

U kontekstu Ujedinjenog Kraljevstva postoje brojni separatni elementi sportske diplomacije, poput partnerske inicijative naziva "Premier Skills" između Britanskog vijeća i nogometne Premier lige ili međunarodnog 


\section{6 \\ POLITIČKE PERSPEKTIVE}

ČLANCI I STUDIJE

partnerstva između američkog Try Rugbyja i britanskog Premiership Rugbyja (Grassroots Sport Diplomacy 2018). U Ujedinjenom Kraljevstvu je prepoznata i važnost tjelesnog odgoja, ali i važnost ostvarenja velikih sportskih postignuća u svrhu postizanja nadmoći na međunarodnoj sceni, u svrhu čega su u sustav sporta uključena različita državna tijela, zaklade, privatni ulagači itd. U okviru Olimpijskih igara u Londonu 2012. g. pokrenut je "International Inspirations" program u suradnji UNICEF-a, UK Sport, Youth Sport Trust i Zaklade International Inspiration, u svrhu korištenja dobrobiti domaćinstva Olimpijskih igara za prosperitet u raznim sferama društvenoga života (British Council 2019). Guardian (2015) procjenjuje kako je 680.ooo inozemnih gostiju posjetilo Olimpijske i Paraolimpijske igre u Londonu 2012, što je za domaćina generiralo značajnu ekonomsku dobrobit.

Prema Polou (2015), tijekom proteklih 20 godina, sportska diplomacija u Turskoj korištena je u pogledu stvaranja pozitivnog imidža Turske kao moderne zemlje na međunarodnoj sceni, te u približavanju Europi. Od 200o. godine sportska diplomacija sudjeluje u novoj vanjskoj politici Turske, u sklopu politike međunarodne suradnje (uspostavljena od Turske agencije za međunarodnu suradnju i razvoj) i kulturne diplomacije. Glavni ciljevi sportske diplomacije usmjereni su isticanju Turske kao dobronamjerne suvremene zemlje s ambicioznom vanjskom politikom, efikasnom ekonomijom, te stabilnom Vladom (Polo 2015). U kontekstu kandidature Istanbula za Olimpijske igre 2020, koje bi bile podloga za promidžbu „nove Turske" (Polo 2015), završili su stepenicu ispod Tokija.

Kina svoj model sportske diplomacije temelji na ulaganju u snažan sustav sporta, kako bi sportski rezultati generirali meku moć države na međunarodnoj sceni (Leite and Rodrigues 2017). Nakon provedene učinkovite sveobuhvatne olimpijske strategije koja je rezultirala velikim brojem medalja njihovih sportaša na OI u Pekingu 2008, a smatrajući kako sportska nadmoć ima važnu međunarodnu ulogu, kineski predsjednik Hun Jintao istaknuo je kako je vrijeme za prelazak iz zemlje velikih sportskih događaja u zemlju velikih sportskih rezultata (Leite and Rodrigues 2017). Da bi postigla tu ambiciju, Kina vjeruje da je potrebno dominirati najpopularnijim sportom na svijetu, nogometom. Pokrenuli su „Plan razvoja nogometa u srednjoročnom i dugoročnom razdoblju 2016-2050", s ciljem pretvaranja zemlje u eminentnu nogometnu silu. Formirani su glavni ciljevi do 2050: domaćinstvo jednoga Svjetskoga prvenstva, te osvajanje Svjetskoga prvenstva (Leite and Rodrigues 2017). Da bi to učinila, Vlada je raščlanila strategiju na niz koraka, uključujući razvoj specijaliziranih nogometnih škola i nogometnih igrališta, pružajući time potrebnu infrastrukturu za razvoj muških i ženskih timova. Vlada želi iskoristiti meku moć popularnog nogometa u jačanju međunarodnog ugleda, jačanju diplomatskih 
LUKA LEŠKO

PREGLED NACIONALNIH MODELA SPORTSKE DIPLOMACIJE U SVIJETU I PERSPEKTIVA RAZVOJA HRVATSKOG MODELA SPORTSKE DIPLOMACIJE

veza, ali i osjećaja nacionalnog identiteta. Iako pod snažnom kontrolom Vlade, Kina se u ovome kontekstu oslanja i na sudjelovanje privatnog sektora (Leite and Rodrigues 2017).

U Japanu je Vlada 2013. g. objavila program "Sport for Tomorrow", koji obuhvaća korištenje meke moći sporta za učvršćivanje mira u regiji, razvoj japanskog sportskog ekosistema i uspostavljanje temelja za promicanje sportske diplomacije (Grassroots Sport Diplomacy 2018). Japansko Ministarstvo vanjskih poslova uglavnom koristi nogomet i nogometaše u svrhu sportske diplomacije. Jedna od temeljnih namjera formiranja Japanske nogometne lige (J1) u devedesetima, bila je poboljšati performanse nacionalnog tima kako bi sport na međunarodnom planu odražavao korak s japanskom ekonomskom moći (Manzenreiter 2008). U 21. stoljeću Ministarstvo vanjskih poslova koristilo je nogomet u očuvanju stabilnog okruženja za japanske trupe u Iraku, a često poziva izraelske i palestinske mlade igrače na zajedničke trening kampove u Japan, u svrhu smanjenja nesnošljivosti između ta dva naroda (Manzenreiter 2008).

Zemlja u kojoj je osvjedočen trnovit put sportskoj diplomaciji jest Brazil. Država je to koja je posebno vezana uz sport, gdje se istaknute sportaše poput Garrinche, Pelea ili Senne slavi kao nacionalne junake. Nogomet je bez presedana njihov nacionalni sport. Iako sportska diplomacija može generirati brojne pozitivne učinke, u Brazilu je nerijetko nailazila na neodobravanje naroda, često iz objektivnih razloga poput ulaganja u sportsku infrastrukturu nauštrb ulaganja u obrazovanje i zdravstvo (Alhamdi 2013). Organizacije Svjetskog nogometnog prvenstva 2014, odnosno Olimpijskih igara 2016. nisu bile lišene prosvjeda. Rocha i Grix (2017) zaključuju kako ekonomska situacija u Brazilu uvjetuje da je organizacija velikih sportskih događaja u toj zemlji mač s dvostrukom oštricom.

Temeljem navedenih primjera, sumirani učinci sportske diplomacije uključuju: kreiranje imidža države, širenje njezinog međunarodnog utjecaja, slanje diplomatskih poruka, testiranje uvjeta za diplomatske pregovore, rješavanje sukoba i očuvanje mira, socijalnu inkluziju, jačanje regionalne (i međunarodne suradnje), korištenje sporta kao potpore investicijskom, ekonomskom, demografskom i turističkom razvoju itd. Takvi se učinci ostvaruju putem nacionalnih modela sportske diplomacije (nacionalne strategije, separatni partnerski programi i sl.), koji obuhvaćaju: korištenje sportske uspješnosti u jačanju meke moći države, uključenje sportaša u političke i diplomatske procese, korištenje sporta kao diplomatskog instrumenta putem međunarodnih razvojnih programa, organizaciju velikih sportskih priredbi i onih manje poznatih, ali tradicionalnih međunarodnih sportskih događaja. 
POLITIČKE PERSPEKTIVE

ČLANCI I STUDIJE

\section{Perspektiva razvoja hrvatskog modela SPORTSKE DIPLOMACIJE}

Temeljem prikazanih modela sportske diplomacije u svijetu, pokušat će se identificirati područja u kojima hrvatski sport može generirati pozitivan doprinos ostvarenju ciljeva Republike Hrvatske. Osvajanje medalja na velikim sportskim natjecanjima koristi međunarodnom brendiranju države, a sportska uspješnost postala je sastavnim čimbenikom ukupnog međunarodnog indeksa meke moći (McClory 2012; Portland's in-house Content \& Brand team 2018), zbog čega se vjeruje kako sport utječe na globalnu percepciju zemalja (The Anholt-GfK Roper Nation Brands Index 2009; Rapid-growth markets soft power index 2012). Javna diplomacija posebno je važna za manje zemlje, nudeći im priliku da steknu utjecaj i oblikuju međunarodni imidž unatoč nedostatku tzv. tvrde moći, pri čemu je međunarodna prepoznatljivost jedan od krucijalnih ciljeva (Bátora 2005). Autoritativni njemački "Bild” (2018) proglasio je Hrvatsku najuspješnijom sportskom nacijom na svijetu, s obzirom na veličinu države. Uz Hrvatsku, samo četirima zemljama je pošlo za rukom osvojiti više od jedne medalje tijekom posljednjih šest Svjetskih prvenstava u nogometu, globalno najpopularnijem sportu. Iako je osvjedočena moć nogometa u masovnom pokretanju nacije, hrvatski sport nije samo nogomet, što najbolje oslikava činjenica da je Hrvatska trećeplasirana zemlja Olimpijskih igara 2016. g. u Rio de Janeiru, prema broju osvojenih zlatnih medalja po broju stanovnika. Hrvatski reprezentativci penjali su se na najviša svjetska i europska postolja u nizu ekipnih i individualnih sportova (košarka, rukomet, vaterpolo, veslanje, jedrenje, tenis, alpsko skijanje, atletika, borilački sportovi itd.). U članku 1. Zakona o sportu Republike Hrvatske (Hrvatski sabor 2015) stoji kako su sportske djelatnosti od posebnog interesa za Republiku Hrvatsku. Važnost sporta prepoznata je i u aktualnoj Strategiji nacionalne sigurnosti Republike Hrvatske, u kojoj stoji kako će država koristiti zapažene sportske uspjehe u svrhu širenja svojega ugleda (Hrvatski sabor 2017). U razdoblju do osamostaljenja, tijekom perioda osamostaljenja, sve do današnjih dana kada je nogometna reprezentacija srebrnom medaljom na Svjetskom nogometnom prvenstvu postigla najveći nacionalni sportski uspjeh, oslikava se meka moć sporta u kreiranju imidža hrvatske države. Naklonost i razumijevanje za sport osobito je iskazivao prvi predsjednik Republike Hrvatske Franjo Tuđman (Bartoluci 2013), a diplomatsku moć sporta u više je navrata isticala i predsjednica Kolinda Grabar-Kitarović, kao i brojni hrvatski diplomati. Sport je odigrao značajnu ulogu u konstruiranju i snaženju nacionalnog identiteta i međunarodnog ugleda Republike Hrvatske, ima specifično veliku važnost za hrvatski narod u zemlji i dijaspori stoga nije pretjerano konstatirati da je Republika Hrvatska već na neki način brendirana kao sportska zemlja. Nameće se mišljenje kako su u 
LUKA LEŠKO

PREGLED NACIONALNIH MODELA SPORTSKE DIPLOMACIJE U SVIJETU I PERSPEKTIVA RAZVOJA HRVATSKOG MODELA SPORTSKE DIPLOMACIJE

Hrvatskoj primjenjiva oba oblika sportske diplomacije (prema Murrayju i Pigmanu 2014), uporaba sportskih postignuća kao instrumenata diplomacije (sportska kompetitivnost), odnosno uporaba sporta u svrhu komunikacije, pregovora i slanja diplomatskih poruka. Prema izvješću Europske komisije (2018), prepoznat je potencijal sporta u unaprjeđenju vanjske politike i međunarodnih odnosa, poboljšanju imidža i utjecaja država na međunarodnoj sceni. Analizom primjera modela sportske diplomacije diljem svijeta, osim netom navedenih, potencijalne dobrobiti sporta za Republiku Hrvatsku očituju se i u jačanju nacionalnog identiteta (kohezije), osiguranju mira, rješavanju sukoba, jačanju diplomatskih veza, kao i turističkoj, kulturnoj i demografskoj dobrobiti. Sport može poslužiti i podlogom za dijalog i ostvarenje poslovnih partnerstava (povezivanje ljudi i institucija), doprinoseći ekonomskoj i investicijskoj dobrobiti. Brojni autori, poput Zagnoli i Radicchi (2009), ističu ekonomsku i turističku dobrobit sporta. Benefiti sporta nalaze se i u javnozdravstvenoj politici (sport i tjelesna aktivnost u svrhu usvajanja zdravih životnih navika, prevencije nezaraznih srčano-žilnih i metaboličkih bolesti itd.), te u području socijalne inkluzije (posebno ranjive skupine, podrška osobama s invaliditetom itd.). Pozitivni učinci sporta mogu se promatrati i u kontekstu aktualnih migracijskih tokova, jačanju kulture volonterizma, demonstraciji stručnosti u području organizacije sportskih događaja (know-how), te razvoju domicilnog i regionalnog sportskog ekosistema potičući inovativnost u sportskoj industriji, sportskoj medicini i prehrani, s naglaskom na izvozne kapacitete. Osim vrhunskog sporta, pažnju valja usmjeriti i na sport djece, djece s poteškoćama u razvoju, rekreativni sport, sport osoba s invaliditetom, masovne humanitarne sportske događaje, te iskoristivost velikih kapaciteta Hrvatske u sportskom i sportsko-zdravstvenom turizmu. Prema UNWTO-u, sportski se turizam definira kao aktivnosti sportaša, osoba koje se sportom bave iz rekreativnih razloga, gledatelja i putnika, koje poduzimaju u mjestima izvan njihovog uobičajenog mjesta boravka u razdoblju ne duljem od godine dana, a radi sudjelovanja u sportu, praćenju sporta i odmoru motiviranom sportskim razlozima (Bartoluci, Škorić i Šindilj 2013). Prema Prijedlogu strategije razvoja turizma Republike Hrvatske do 2020. g. (Ministarstvo turizma 2012), Hrvatska zauzima poziciju jedne od vodećih ronilačkih destinacija na Mediteranu, te se uvrštava među pet vodećih europskih destinacija kajaka na moru, poglavito uz razvedenu obalu s velikim brojem otoka. Osim velikih potencijala sportskog turizma na Jadranu, prepoznat je potencijal brdskog biciklizma i raftinga u Gorskoj Hrvatskoj, zatim sportski usmjereni sadržaji u kontinentalnoj Hrvatskoj poput termi itd. (Hasanović 2018). Da sport ima važnu ulogu u proširenju klasične ljetne turističke sezone sugeriraju provedena istraživanja. Tako primjerice, temeljem studije istarskog sportskog turizma, Škorić (2008) 
upućuje da su među ispitanima motivi za sport i sportsku rekreaciju zastupljeniji u vrijeme predsezone nego glavne sezone. Jedna od prednosti Republike Hrvatske u odnosu na neke od prikazanih zemalja podatak je da zauzima visoko 24. mjesto u svijetu po razini sigurnosti u turizmu (Pavlović 2018), što je posebno važno uvažavajući činjenicu kako je sigurnost jedan od krucijalnih faktora u odabiru turističke destinacije.

U kontekstu ostvarenja navedenih ciljeva važna je sustavno prepoznata meka moć sporta od strane države, odnosno podrška izgradnji kvalitetnoga i održivoga sustava sporta, kako sportski rezultati ne bi bili dominantno plod posebno motiviranih i entuzijastičnih sportaša, njihovih obitelji, trenera i mikrookoline, već „proizvod” sustava. Interdisciplinarna i pravovremena identifikacija i predikcija benefita nastupa sportaša na natjecanjima u inozemstvu svakako će doprinijeti efikasnijem upravljanju učincima na strateške ciljeve države. U kontekstu održavanja sportskih događaja, ljetne i zimske Olimpijske igre, te Svjetsko i Europsko nogometno prvenstvo (tzv. mega događaji) najznačajniji su zbog svoje popularnosti i globalnih razmjera (Kobierecki 2017). Takvi događaji zahtijevaju velika financijska ulaganja u sportsku, ali i ostalu popratnu infrastrukturu, te se moraju uklopiti u dugoročni strateški plan grada domaćina, u cilju ekonomske održivosti (Solberg and Preuss 2007). Međutim, osim niza već navedenih pozitivnih, postoje i određeni negativni učinci uvjetovani organizacijom najvećih sportskih manifestacija. Odnosi se to na raseljavanje lokalne zajednice (Sudworth 2006), prenapučenost i pojačane sigurnosne mjere koje mogu utjecati na civilnu slobodu građana (King 2016), onečišćenje okoliša i društveno neodobravanje (Yichen i sur. 2011). Hrvatska nema kapaciteta za organizaciju takvih manifestacija, ali se pokazala kvalitetnim domaćinom ostalih međunarodnih natjecanja poput Univerzijade 1987, te Europskih sveučilišnih igara 2016, što su manifestacije koje su brojale po više od 5 .ooo sudionika (sportske delegacije) iz cijeloga svijeta. Također, ugošćena su natjecanja poput Svjetskoga rukometnog prvenstva, Europskoga vaterpolo prvenstva itd. Moderna je tendencija zajedničkih međunarodnih domaćinstava velikih natjecanja, u čemu valja potražiti priliku za jačanje i očuvanje međudržavnih partnerstava. Ne treba zaboraviti kako i sam sustav natjecanja u nekim sportovima osigurava velik broj međunarodnih sportskih mečeva na hrvatskom tlu, u reprezentativnom i klupskom smislu, a što ne iziskuje posebnu kandidaturu. Važno je očuvati napore i u neprekidnom održavanju tradicionalnih međunarodnih sportskih natjecanja po kojima je Hrvatska prepoznata (poput umaškog “Croatia Opena”, „Snježne kraljice”, „Zlatne piruete”, „Regate Sv. Duje”, biciklističkog “Tour of Croatia” itd.), uz kreiranje aktivnih mjera poticanja stranih posjetitelja na dolazak na sportske događaje u Hrvatskoj. Mikulić (2017) primjerice ukazuje da su stavovi lokalnih posjetitelja 
o ekonomskim i društvenim učincima sportskih manifestacija u Splitu pretežno pozitivni. Valja podrobnije razmotriti i uključivanje istaknutih sportaša u političke i diplomatske procese, te političke posjete inozemstvu, odnosno imenovanje sportskih ambasadora, uključujući kreiranje specifičnih edukacijskih programa. Također, važna je prisutnost hrvatskih povjerenika u tijelima krovnih međunarodnih sportskih organizacija. Od potencijalne uzajamne koristi može biti pružanje potpore sportski usmjerenim tvrtkama i organizacijama u tržišnom nadmetanju, odnosno kandidaturi za organizaciju sportskih priredbi, kao i potpora inovacijama i regionalnoj suradnji u obrazovanju, osposobljavanju i profesionalnom razvoju putem razvojnih sportskih projekata, u svrhu jačanja međunarodnih partnerstava. Navedeni ciljevi, ovisno o modelu, ostvaruju se uglavnom međuresornom suradnjom državnih tijela (npr. Ministarstvo vanjskih poslova, Ministarstvo turizma i Ministarstvo/Ured za sport), sportskih organizacija (nacionalnih, regionalnih i lokalnih), sportskih diplomata, međunarodnom suradnjom, a potpomognuto je državnim ulaganjima, međunarodnim projektnim financiranjem, privatnim sektorom i volonterskim radom. Kako učinci koje generira hrvatski sport ne bi bili prepušteni slučaju, samoinicijativno i sporadično korišteni, već anticipirani, usmjeravani, upravljani i evaluirani, preporučuje se međuresorna interdisciplinarna izrada strategije sportske diplomacije ili sličnih programa koji će biti decidirani, s jasnim mehanizmima provedbe. S obzirom na različite modele javne diplomacije od države do države, važno je sportsku diplomaciju uklopiti u formu dosadašnjih tradicionalnih modela hrvatske diplomacije, kako bi poslužila njenoj efikasnoj nadogradnji. Unatoč činjenici da se prikazani primjeri diljem svijeta odnose na zemlje s višim BDP-om od hrvatskoga, te uglavnom uređenijim sustavom sporta, za zaključiti je kako postoji velik broj društvenih sfera u Hrvatskoj na koje sport može pozitivno utjecati, no taj potencijal još uvijek nije strateški osmišljen. Posebno je to važno uz činjenicu već stečene međunarodne prepoznatljivosti Republike Hrvatske kao sportski uspješne zemlje, što je velikom broju razvijenijih svjetskih zemalja još uvijek teško dostižno.

Sumirano, potencijal sportske diplomacije u Republici Hrvatskoj očituje se u kreiranju imidža i prepoznatljivosti države, testiranju uvjeta za diplomatske pregovore, očuvanju mira, jačanju regionalne (i međunarodne suradnje), korištenju sporta kao potpore investicijskom, ekonomskom, demografskom i turističkom razvoju itd. U Republici Hrvatskoj takvi su učinci ostvarivi putem sustavnog i operacionaliziranog korištenja sportske uspješnosti u jačanju meke moći države, uključenja sportaša u političke i diplomatske procese, korištenja sporta kao diplomatskog instrumenta putem međunarodnih razvojnih programa, te organizacije tradicionalnih međunarodnih sportskih događaja. 
U prvoj rečenici Nacrta prijedloga nacionalnog programa športa 20192026. (Središnji državni ured za šport 2019) stoji kako je sport u Hrvatskoj već desetljećima iznimno važan segment društvenog života, ali segment o kojemu se vrlo rijetko strateški i cjelovito promišlja. SWOT analiza u okviru tog dokumenta, između ostaloga, prepoznaje snagu Hrvatske u kontinuiranom postizanju vrhunskih sportskih rezultata, te vrhunske sportaše kao promotore zemlje, zatim prijetnje u pogledu neprepoznavanja sporta kao važne društvene pojave, te njegove ekonomske, socijalne i ostale uloge, a shodno tomu ističe prilike u vidu marketinške iskoristivosti bogate sportske baštine i sportaša koji kontinuirano postižu vrhunske sportske rezultate. Shodno navedenom, važnost ove studije jest u prikazu različitih nacionalnih modela sportske diplomacije u svijetu, te u ukazivanju na potencijal sportske diplomacije Republike Hrvatske. U znanstvenom, ali i praktičnom (policy) smislu, ova studija može poslužiti kao jedna od podloga za međuresornu izradu nacionalne strategije sportske diplomacije ili separatnih programa sa sličnim ciljevima, a ukoliko do toga dođe od važnosti je praćenje, evaluacija i izvještavanje o njihovim učincima, u svrhu dugoročnog povećanja efikasnosti korištenja dobrobiti sporta u različitim sferama društvenog života. Interdisciplinarnost se nameće nužnom uz činjenicu da učinci sporta prelaze okvire isključivo sportskog resora.

\section{ZAKLJUČAK}

Temeljeno na konceptu meke moći (soft power), ulogu sporta kao sredstva diplomacije zagovaraju predstavnici konstruktivističke teorije međunarodnih odnosa. Pozitivni učinci sporta na državne ciljeve ostvaruju se putem nacionalnih modela sportske diplomacije (nacionalne strategije, separatni partnerski programi i sl.), koji obuhvaćaju: korištenje sportske uspješnosti u jačanju meke moći države, uključenje sportaša u političke i diplomatske procese, korištenje sporta kao diplomatskog instrumenta putem međunarodnih razvojnih programa, organizaciju velikih sportskih priredbi i onih manje poznatih, ali tradicionalnih međunarodnih sportskih događaja itd. Iako je dobrobit sporta za Republiku Hrvatsku opće prepoznata, još uvijek nije strateški osmišljena. Identificirana su područja na koja hrvatski sport može pozitivno utjecati, poput unaprjeđenja vanjske politike i međunarodnih odnosa, poboljšanja imidža države u svijetu, jačanja nacionalne kohezije, turističke, kulturne, demografske, ekonomske i javnozdravstvene dobrobiti, socijalne inkluzije, jačanja kulture volonterizma itd. Sustavno prepoznata važnost sporta od strane države, odnosno podrška izgradnji kvalitetnoga i održivoga sustava sporta, od krucijalnog su značaja. Preporučuje se međuresorna izrada nacionalne strategije sportske diplomacije ili separatnih programa sa sličnim ciljevima. 


\section{LITERATURA}

Abend, Lisa. 2014. Why Nobody Wants to Host the 2022 Winter Olympics. Time (mrežni izvor, pristupljeno o1. veljače 2019. http://time.com/3462070/olympics-winter-2022/)

Fairuz, Alhamdi. 2013. Football as Brazilian tool of soft power and public diplomacy \& challenge. (mrežni izvor, pristupljeno o1. veljače 2019. http://www.academia.edu/5546654/FOOTBALL_AS_BRAZILIAN_TOOL_OF_SOFT_POWER_ AND_PUBLIC_DIPLOMACY_and_CHALLENGES)

Aubin, Lukas. 2017. “What sport power for Russia?" Herodote, 3: 189-202. doi: 10.3917/her.166.0189

Australian Sports Diplomacy Strategy 2015-18. 2015. Australian Government (mrežni izvor, pristupljeno o1. veljače 2019. https://dfat.gov.au/about-us/publications/Documents/aus-sports-diplomacy-strategy-2015-18.pdf)

Auswartiges Amt. 2010. People on theMove: Overcoming Borders (mrežni izvor, pristupljeno o1. veljače 2019. http://www.auswaertiges-amt.de/EN/Ausshenpolitik/KulturDialog/Initiativen/Sport2o10-Konzept_node.html)

Bamossy, Gary J. and Stephens, Stephen. 2003. Utah image and awareness. The post-Olympics European study.

Bartoluci, Sunčica. 2013. Uloga vrhunskog sporta u oblikovanju nacionalnog identiteta u Republici Hrvatskoj: usporedba devedesetih i dvijetisućitih. Doktorska disertacija. Filozofski fakultet Sveučilišta u Zagrebu.

Bartoluci, Mato, Škorić, Sanela i Šindilj, Matea. 2013. „Modeli organizacije i kvaliteta sportsko-rekreacijskog turizma u Istri”. U ur. Findak, Vladimir. Zbornik radova 22. ljetne škole kineziologa Republike Hrvatske. Hrvatski kineziološki savez.

Bátora, Jozef. 2005. Public Diplomacy in Small and Medium-Seized States: Norway and Canada. Netherlands institute of International Relations 'Clingendael'.

Bild. 2018. Kroatien, das beste Sportland der Welt (mrežni izvor, pristupljeno o1. veljače 2019. https://www.bild.de/sport/fussball/fifa-wm-2018/kroatien-dasbeste-sportland-der-welt-56095358.bild.html)

British Council. 2019. International Inspiration (mrežni izvor, preuzeto 02. veljače 2019. https://www.britishcouncil.org/society/sport/current-programmes/ international-inspiration)

Bureau of Educational and Cultural Affairs. 2019. Global Sports Mentoring Program (mrežni izvor, preuzeto 02. veljače 2019. https://eca.state.gov/programsinitiatives/initiatives/sports-diplomacy/global-sports-mentoring-program/ global-sports)

Cashmore, Ellis. 2005. Making Sense of Sports. London: Routledge. https://doi.o $\mathrm{rg} / 10.4324 / 9780203518953$ 
Chalip, Laurence, Green, Christine Beverly and Hill, Brad. 2003. "Effects of sport event media on destination image and intention to visit". Journal of Sport Management, 17: 214-34. https://doi.org/10.1123/jsm.17.3.214

Department of Foreign Affairs and Trade of Australian Government. 2015. Australian Sports Diplomacy Strategy 2015-18 (mrežni izvor, preuzeto 12. siječnja 2019. https://dfat.gov.au/about-us/publications/Pages/australian-sports-diplomacy-strategy-2015-18.aspx)

Europska komisija. 2018. Sport Diplomacy: Identifying good practices. Luxembourg: Publications Office of the European Union.

Europska unija. 2019. Sport diplomacy (mrežni izvor, preuzeto 03. veljače 2019. https://publications.europa.eu/en/publication-detail/-/publication/oefcoga6o25e-11e8-b8f5-oraa75ed71a1/language-en/format-PDF)

Frazier, Derrick and Stewart-Ingersoll Robert. 2010. "Regional powers and security: A framework for understanding order within regional security complexes“. European Journal of International Relations, 16 (4): 731-53. https://doi.org/10. 1177/1354066109359847

France Diplomatie. 2019. Mrežni izvor, preuzeto 03. veljače 2019. https://www. diplomatie.gouv.fr/IMG/pdf/diplomatie_sportive-version-accessible_ang_ cleo63b27.pdf

Grassroots Sport Diplomacy. Overview, mapping and definitions. 2018. European Commission (mrežni izvor, preuzeto 14. siječnja 2019. http://isca-web.org/files/Grassroots_Sport_Diplomacy/Grassroots_Sport_Diplomacy_-_Overview_ mapping_definitions[1].pdf)

Guardian. 2015. Lots of economic benefits can come from sport tourism (mrežni izvor, preuzeto 28. siječnja 2019: http://www.guardian.co.tt/sport/lots-economic-benefits-can-come-sport-tourism-6.2.368958.9dd6d6bf3e)

Haralambos, Michael i Martin Holborn. 2002. Sociologija: Teme i perspektive. Zagreb: Golden marketing.

Hasanović, Petra. 2018. Sportski turizam kao marketinški element pozicioniranja Hrvatske kao turističke destinacije. Završni rad. Međimursko Veleučilište u Čakovcu.

Houlihan, Barrie. 1994. Sports and International Politics. Hertfordshire: Harvester Wheatsheaf.

Hrvatski sabor. 2015. Zakon o sportu.

Hrvatski sabor. 2017. Strategija nacionalne sigurnosti Republike Hrvatske.

Jackson, Steven J. and Haigh, Stephen. 2008. "Between and Beyond Politics: Sport and Foreign Policy in a Globalizing World”. Sport in Society, 11(4): 349-58. https://doi.org/10.1080/17430430802019169

Jackson, Robert and Sørensen, Georg. 2007. Introduction to International Relations, Theories and Approaches. New York: Oxford University Press. 
Jarvie, Gtanr T. 2015. The soft power of sport can win friends (mrežni izvor, preuzeto 22. siječnja 2019. https://www.ed.ac.uk/files/imports/fileManager/GrantJarvies-InauguralLecture-text-2014.pdf)

Kalanj, Rade. 2010. Ideologija, utopija, moć. Zagreb: Naklada Jesenski i Turk.

Keech, Marc. 2001. "The Ties that Bind: South Africa and Sport diplomacy 1958 1963". The Sport Historian, 21(1): 71-93. https://doi.org/10.1080/174602601094 43377

King, Neil. 2016. “Sport, Terrorism, National Security, and the 'Deep State': Components of a Longitudinal Research Programme”. In Ed. Harvey A. and Kimball R. Sport: Identity and Community. Oxford: Inter-Disciplinary Press: 51-62.

Kobierecki, Michał Marcin. 2017. "Sports diplomacy of Norway”. Interdisciplinary political and cultural journal, 20(1): 131-146. http://dx.doi.org/10.1515/ipcj-20170021

Leite, Emanuel Ferreira Junior and Rodrigues, Carlos. 2017. "The Chinese football development plan soft power and national identity”. Holos, 33(5): 114-24. doi: 10.15628/holos.2017.5750

Levermore, Roger and Buss, Adrian. 2004. Sport and International Relations: an emerging relationship. New York: Routledge. https://doi.org/10.4324/978020 3497234

Luša, Đana. 2016. „Sport, politika i diplomacija: analiza iz konstruktivističke perspektive". U ur. Jović, Dejan. Konstruktivističke teorije međunarodnih odnosa. Zagreb: Političke analize: 229-83.

Mabillard, Vincent and Jadi, Daniel. 2011. Sports as Cultural Diplomacy How Sport Can Make a Difference in Intercultural Relations. Institute for Cultural diplomacy.

Manurung, Hendra. 2018. World Cup 2018 \& Russia Soft Power (mrežni izvor, preuzeto o1. veljače 2019. https://www.researchgate.net/publication/326657917_ World_Cup_2018_Russia_Soft_Power)

Mattingly, Garret. 1938. "An Early Nonaggression Pact". Journal of Modern History, 10(1): 1-30.

Manzenreiter, Wolfram. 20o8. "Football Diplomacy, Post-Colonialism and Japan's Quest for Normal State Status". Sport in Society, 11(4): 414-28. https://doi.org /10.1080/17430430802019359

McClory, Jonthan. 2012. The New Persuaders III: A 2012 Global Ranking of Soft Power. Institute for Government

Mikulić, Anja. 2017. Percepcije lokalnih posjetitelja o učincima sportskih manifestacija. Diplomski rad. Sveučilište u Splitu: Ekonomski fakultet.

Mingst, Karen A. and Snyder, Jack L. 2014. Essential Readings in World Politics. New York: W. W. Northon \& Co. 
Ministarstvo turizma. 2012. Prijedlog strategije razvoja turizma Republike Hrvatske do 2020. godine.

Murray, Stuart. 2011. "Sports Diplomacy: A Hybrid of Two Halves”. Cultural Diplomacy (mrežni izvor, preuzeto 20. siječnja 2019: http://www.culturaldiplomacy.org/academy/content/pdf/participant-papers/2011-symposium/Sports-Diplomacy-a-hybrid-of-two-halves--Dr-Stuart-Murray.pdf)

Murray, Stuart. 2018. Sports Diplomacy: Origins, Theory and Practice. London: Routledge.

Murray, Stuart and Pigman, Geoffrey Allen. 2014. "Mapping the relationship between international sport and diplomacy". Sport in Society: Cultures, Commerce, Media, Politics, 17(9): 1098-1118. https://doi.org/10.1080/17430437.2013.856616

Muzhikbaev, Leo. 2014. “The Phenomenon of Sports Diplomacy in Modern International Relations”. (mrežni izvor, preuzeto o1. travnja 2019. https://sites.google.com/site/ culthuman/proceedings-2014/the-phenomenon-of-sports-diplomacy - in-modern-international-relations)

Nye, Joseph S. 2004. Soft Power: The Means to Success in World Politics. PublicAffairs, New York.

Ociepka, Beata. 2013. Miękka siła i dyplomacja publiczna Polski. Wydawnictwo Naukowe Scholar, Warszawa.

Oldenboom, Egbert Roelof. 2006. Costs and benefits of major sports events. A case study of Euro 200o. Amsterdam: MeerWaarde Onderzoeksadvies.

Pamment, James. 2016. "Rethinking Diplomatic and Development Outcomes through Sport: Toward a Participatory Paradigm of Multi-Stakeholder Diplomacy". Diplomacy E Statecraft, 27(2): 231-50. https://doi.org/10.1080/09592296 .2016 .1169787

Pavlović, Dorijan. 2018. „Sigurnosna strategija u turističkom sektoru Republike $\mathrm{Hr}$ vatske". U urs. Anđelinović, Šimun i sur. Zbornik radova 2. međunarodne konferencije 'Sigurnost povijesnih gradova - izazovi turizma': 77-85.

Perasović, Benjamin i Bartoluci, Sunčica. 2007. „Sociologija sporta u hrvatskom kontekstu". Sociologija i prostor, 175(1): 105-120.

Polo Jean-François. 2015. "Turkish sports diplomacy in the service of renewed power? The uses and limits of Turkey's "sport power". European Journal of Turkish Studies, 21(1).

Rapid-growth markets soft power index Spring 2012. 2012. Enrst \& Young with Skolkovo (mrežni izvor, preuzeto 12. siječnja 2019. https://www.ey.com/Publication/vwLUAssets/Rapid-growth_markets:_Soft_power_index/\%24FILE/Rapidgrowth_markets-Soft_Power_Index-Spring_2012.pdf)

Redeker, Robert. 2008. "Sport as an Opiate of International Relations: The Myth and Illusion of Sport as a Tool of Foreign Diplomacy". Sport in Society, 11(4): 494-50o. https://doi.org/10.1080/17430430802019482 
Rocha, Claudio and Grix, Jonathan. 2017. "From 'Diplomatic Dwarf' to Gulliver Unbound? Brazil and the Use of Sports Mega-Events". In Ed. Esherick, Baker, Jackson and Sam. Case Studies in Sport Diplomacy. Morgantown, WV. FiT Publishing: 1-27.

Rupert, James. 2011. Cricket Diplomacy May Smooth Tension Between India, Pakistan. Bloomberg (mrežni izvor, preuzeto 14. siječnja 2019. http://www.bloomberg.com/news/2011-03-28/ cricket-diplomacy-at-world-cup-may-smoothtension-between-india-pakistan)

Solberg, Harry Arne and Preuss, Holger. 2007. "Major Sport Events and LongTerm Tourism Impacts”. Journal of Sport Management, 21: 215-36. doi: 10.1123/ jsm.21.2.213

Sprecher Mary Helen. 2018. Champions of economic impact in sports tourism (mrežni izvor, preuzeto 22. siječnja 2019. https://www.sportsdestinations.com/ management/economics/2018-champions-economic-impact-sports-tourism15586)

Sudworth, John. 2006. Slum dispute over Commonwealth Games. BBC News (mrežni izvor, preuzeto 03. siječnja 2019. http://news.bbc.co.uk/2/hi/south asia/5325034.stm)

Škorić, Sanela. 2008. „Sportski turizam i njegovi učinci na turističke destinacije primjer Istre”. Acta turistica, 20(1): 67-92.

Taylor, Trevor. 1986. "Sport and International Relations: A Case of Mutual Neglect”. In ed. Allison, L. The Politics of Sport. Manchester: Manchester University Press: 27-49.

The Anholt-GfK Roper Nation Brands Index. 2009. GfK Roper Public Affairs \& Media. Prepared for Switzerland.

Portland's in-house Content \& Brand team. 2018. The Soft Power 30. A Global Ranking of Soft Power.

Velikaya, Anna. 2016. Russian sports diplomacy: nation branding \& peacebuilding. CPD Blog (mrežni izvor, preuzeto 17. siječnja 2019. https://www.uscpublicdiplomacy.org/blog/russian-sports-diplomacy-nation-branding-peacebuilding)

Walt, Stephen M. 1998. International Relations: One World, Many Theories. Foreign Affairs. 110: 29-32; 34-46.

Walters, Carrie. 2007. Sports Diplomacy is the New Comeback Kid. CPD Blog (mrežni izvor, preuzeto 17. siječnja 2019. https://www.uscpublicdiplomacy.org/ blog/sports-diplomacy-new-comeback-kid)

Weber, Max. 2013. Vlast i politika. Zagreb: Naklada Jesenski i Turk i Hrvatsko sociološko društvo.

Winstanley, K. L. 2009. Scottish Football and Northern Ireland: The Role of Sport in Communal Identification and Ethnonational Conflict. Canadian Political Science Association Conference. Carlton University, Ottawa, Canada: 27-29. 
Yichen, Han, Haojie Sun, Yu, Dong and Yong, Li. 2011. "The Sports Tourism Impacts - the Case Study of Olympics Event". International Conference on Future Computer Science and Education: 71-74. doi: 10.1109/ICFCSE.2011.26

Zagnoli, Patrizia and Radicchi, Elena. 2009. "Do Major Sports Events Enhance Tourism Destinations?" Physical culture and sport studies and research, 47:4463. doi: 10.2478/v10141-009-0031-z

\section{SUMMARY}

\section{REVIEW OF NATIONAL MODELS OF SPORTS DIPLOMACY IN THE WORLD AND THE DEVELOPMENT PERSPECTIVES OF THE CROATIAN MODEL OF SPORTS DIPLOMACY}

The role of sport as a tool of diplomacy is recognized by representatives of the constructivist theory of international relations. The aim of the study is to give a review of several national models of sports diplomacy (Australia, France, USA, Norway, Russia, China, Japan, Brazil) in the world and to point to the opportunities for developing a Croatian model of sports diplomacy. The positive effects of sport on national goals may be achieved through models which include: the use of sporting success in strengthening soft power of the country, involving athletes in political and diplomatic processes, use of sport as a diplomatic instrument through international development programs, the organization of sporting events etc. The potential areas in which Croatian sport may have a positive influence are: international relations; improving the image of the country in the world; strengthening national cohesion; tourism, demography, economy and public health; social inclusion; strengthening the culture of volunteerism etc. It is crucial for a country to recognize the potentials of sports in these many areas of social and political life. An interdepartmental creation of a national sports diplomacy strategy or separate programs with similar goals is recommended.

KEYWORDS: soft power, strategy, international relations, foreign affairs, Olympic Games. 